\title{
Editorial
}

\section{Treinamento de alta intensidade ou contínuo?}

\author{
Paulo Farinatti
}

Nos últimos tempos, percebe-se uma grande discussão acerca do papel da intensidade do exercício em programas de treinamento direcionados para populaçôes diversas. Recentemente, resultados de estudo realizado por grupo envolvendo pesquisadores do Rio de Janeiro, foram divulgados pela mídia impressa e televisiva, o que deu mais impulso ao debate. Naquele estudo, foi proposto que cardiopatas poderiam se beneficiar, em relação a determinados marcadores de eficiência cardiorrespiratória, mais em virtude de treinamento intervalado de alta intensidade do que de programas tradicionais de treinamento contínuo.

Esse debate é muito antigo e, no nosso entender, vem perdendo um pouco o foco. Na verdade, não existem grandes novidades no tocante ao treinamento intervalado em si, sistema conhecido e aplicado por profissionais do exercício físico há décadas. Também não se pode dizer que seja inovadora a ideia de que, trabalhando-se com intensidades maiores, adaptaçóes mais rápidas e pronunciadas no sistema cardiorrespiratória devem ocorrer.

O debate desvia-se um pouco de seu eixo, quando a discussão gira em torno de questôes já definidas e, de certa forma, consensuais. Por outro lado, a discussão pode contribuir com a prescrição do exercício, quando se consideram as possibilidades de treinar com intensidade maior em contextos diferenciados e o quanto esse tipo de estratégia é palatável e segura para grupos especiais. Tomando-se o estudo supracitado, pelo fato de ter ganhado divulgação e vir sendo citado como exemplo, haveria duas formas de interpretá-lo: a) o treinamento intervalado de alta intensidade deve ser o preferencial para cardiopatas; b) o treinamento intervalado de alta intensidade pode ser realizado por esse tipo de paciente, o que náo quer dizer que seja a melhor opção para TODOS os pacientes. Queremos crer que a segunda opção parece mais lógica e equilibrada.

Em prescrição do exercício, notadamente para grupos especiais com histórico de sedentarismo e condições clínicas que demandam cuidado, a máxima de que o "ótimo é inimigo do bom" aplica-se perfeitamente. Deve-se entender que a aceitação de rotinas de exercícios com alta intensidade nem sempre é boa por indivíduos sedentários. Além disso, obviamente esse tipo de rotina aumenta muito os riscos de problemas de natureza osteomioarticular, contribuindo para a evasão de programas de exercícios. Por outro lado, programas de intensidade moderada e com maior ênfase no volume podem ter melhor aceitação e são, igualmente, capazes de induzir melhorias importantes em marcadores de capacidade e eficiência cardiorrespiratória. Em poucas palavras, entende-se que intensidades superiores provocam adaptaçōes mais rápidas e de maior magnitude, mas isso não significa que não se possam obter efeitos clinicamente relevantes com treinamentos de intensidade menor e maior volume. A cada caso devem caber abordagens diferentes, condizentes com as condiçôes clínicas, psicológicas e motivacionais dos praticantes, sejam eles saudáveis ou não.

De qualquer modo, está lançado o convite à reflexão e discussão sobre o assunto. Convidamos os leitores e pesquisadores que contribuem regularmente com a revista a encaminharem textos sobre a temática, sejam posicionamentos embasados em sua experiência ou relatos de caso, sejam estudos originais acerca do papel relativo da intensidade e volume de treinamento sobre desfechos variados e em grupos diversos. Um debate científico e profissional de alto nível contribuirá com o crescimento de todos, em benefício último daqueles que são o propósito de nossas intervençóes, a saber, nossos alunos e pacientes. 